\title{
Chemical and histochemical characterization of mucopolysaccharides in a jaw myxoma
}

\author{
J. J. HODSON AND R. E. S. PROUT
}

From the Departments of Oral Pathology and Biochemistry, University of Sheffield

SYNOPSIS Chemical and histochemical analyses, including testicular and staphylococcal hyaluronio dase digestion, have been made of a jaw myxoma and the results show the presence of two acidu mucopolysaccharides. Of the total mucopolysaccharide present $80 \%$ was hyaluronic acid and $20 \%$ chondroitin sulphate. The high content of non-sulphated mucopolysaccharide would seem tei explain the paucity of fibres characteristic of the myxoma. It is suggested that myxomas generall $\mathrm{y}^{N}$ probably have a similar high hyaluronic acid content. It is considered that the cell concerned is a mesenchymal cell elaborating non-sulphated mucopolysaccharide and may be called a 'myxoblast' is it is metabolically different from the sulphated-mucopolysaccharide-collagen-producing fibroblasto The high hyaluronic acid content is much greater than that found in embryonic connective tissue and may be a significant factor in the neoplastic behaviour of the myxomatous tissue. The aggressive behaviour of the myxoma is against a simple reversion to embryonic mesenchyme. It is concluded that the myxoblast is an active mucopolysaccharide-secreting cell and that mucin in the myxom is not a sign of cell degeneration of preexisting fibroblasts or collagen.

Myxomas are connective tissue tumours composed of stellate fibroblast-like cells dispersed in a metachromatic substance and resembling the myxomatous tissue of the umbilical cord. In pure form, ie, sparse in fibre production, they are rare. The literature shows that by far the largest number occur in the heart. Myxomatous tissue may be present in neoplasms in conjunction with other tissues, as, for instance, in liposarcomas, ameloblastomas, and neurofibromas. The nature of the mucopolysaccharide in the myxomas has not been elucidated, but that found in some other tumours, eg, some mesotheliomas of pleura, has been shown to consist of only hyaluronic acid (Wagner, Munday, and Harington, 1962). Stout (1948) suggested that the soft tissue myxoma might contain hyaluronic acid, and Pearce, Weller, and Steinberg (1952) thought that the fluid in a recurrent myxomatous cyst of the skin was probably hyaluronic acid. Sedano and Gorlin (1965) submitted a jaw myxoma to limited histochemical tests and suggested that it might contain either hyaluronic acid or chrondroitin sulphate.

The myxoma of bone is of particular importance in that, with few possible exceptions (Bauer and Harell, 1954; Perou, Kolis, Zaeske, and Borja 1967), it is only found in the maxilla and mandible. In Received for publication 29 January 1968. behaviour the myxoma is locally infiltrative and may cause extensive bone destruction. It is not know to metastasize. Histologically it is similar to the sof tissue myxomas except that in some cases odonto genic epithelial residues may sometimes be includes within its substance.

In a study of myxomas in the jaws and oral sof tissues those in bone appear to arise from mesen: chyme of the marrow and also, possibly but les? commonly, from myxomatous tissue arising in the follicle of the unerupted tooth crown.

The purpose of the present study was to elucidate the nature of the intercellular material secreted by the cells of the jaw myxoma by chemical analysis and to correlate the findings with those obtained histochemically. The results are discussed from histogenic viewpoint. No myxoma appears to have been previously chemically analysed.

MATERIALS AND METHODS

A girl of 14 presented with a large hard swelling of the body of the right mandible associated with an uneruptef premolar. The tumour had reached and partially resorbed the inferior cortical bone of the mandible. At operation it shelled out fairly easily. Three years after the operation the tumour recurred and a hemimandibulectomy wa\& necessary. Grossly, the mass $(5.0 \mathrm{~cm} \times 4.0 \mathrm{~cm})$ was heavy and slimy and the bisected surface was grey and 


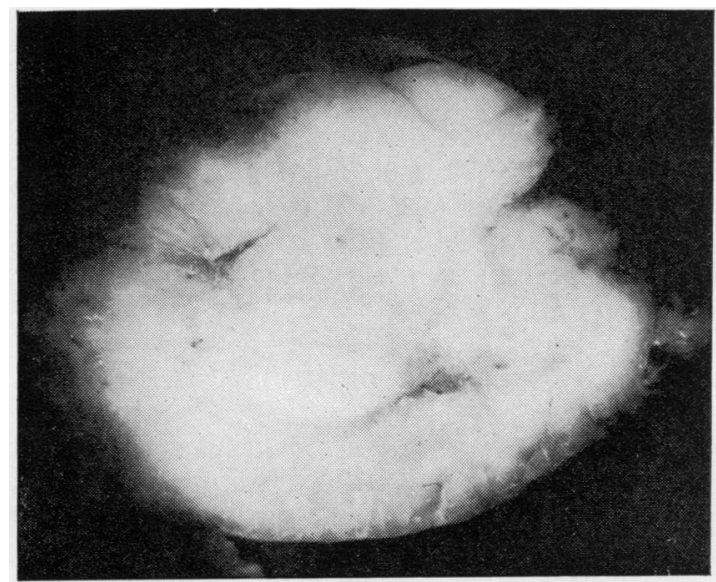

FIG. 1. Cut surface of myxoma. The opaque white oval area in the centre consists of collagen and at the lower border are spicules of bone regenerating from the periosteum.

translucent with small areas of white fibrous tissue (Fig. 1). The tissue was in formalin for a few hours during transit by post. Half of the tumour was stored at $-15^{\circ} \mathrm{C}$ and used for the chemical analysis and part of the other half, after fixation in buffered formol-saline, was used for microscopical and histochemical studies.

\section{CHEMICAL ANALYSES}

The tumour tissue was weighed and homogenized in ice-cold acetone in a Waring blender. The tissue was then extracted with $7 \%(\mathrm{w} / \mathrm{v})$ sodium acetate at $0^{\circ} \mathrm{C}$ for one week. The extract was acidified to $\mathrm{pH} 4$ with acetic acid, treated with 1.5 volumes of ethyl alcohol and allowed to stand at $-15^{\circ} \mathrm{C}$ for $48 \mathrm{hr}$ after which the precipitate was sedimented. A portion of the precipitate in aqueous solution was analysed by electrophoresis using Oxoid cellulose acetate paper and $0.04 \mathrm{M}$ veronal buffer $p \mathrm{H} \mathrm{8.3}$. The samples were run at $20 \mathrm{v} / \mathrm{cm} 2 \mathrm{~m}$ amp for 1.5 hours. The electrophoresis papers were stained for mucopolysaccharide using alcian blue (Heremans and Vaerman, 1958; Näntö, 1963).

Separation of the mucopolysaccharide material was carried out using a column of DEAE Sephadex A25 in the acid state, using $40 \mathrm{ml}$ portions of sodium chloride solution of progressively increasing molarity in $0.01 \mathrm{M}$ hydrochloric acid as eluant (Schmidt, 1962). The eluate fractions were dialysed against distilled water, evaporated to dryness in vacuo and the residue was redissolved in distilled water. Qualitative analysis was carried out by electrophoresis. Quantitative analysis of the uronic acid content of the samples was carried out using the Bitter and Muir (1962) modification of the Dische (1947) carbazole method.

The tissue residue remaining after the initial extraction with sodium acetate was digested with pepsin at $p \mathrm{H} 2$ and $35^{\circ} \mathrm{C}$ for five days. Zinc acetate $(10 \% \mathrm{w} / \mathrm{v})$ was added in equal volume to precipitate any protein present and the solution was then neutralized to $\mathrm{pH} 7 \cdot 2$, filtered and dialysed against water; the dialysate was acidified to pH 4 and mucopolysaccharides were precipitated by the addition of 1.5 volumes of ethyl alcohol.

\section{HISTOCHEMISTRY}

Parts of the tumour from various areas were blocked in paraffin wax and sections cut at 6,10 , and $15 \mu$ thick. Control sections of umbilical cord and mucous salivary gland were used. The chemical analyses by Meyer, Davidson, Linker, and Hoffman (1956) and Balazs and Jeanloz (1965) showed that in addition to hyaluronic acid, the umbilical cord also contains chondroitin sulphate as a minor component. Our histochemical tests with bovine and bacterial hyaluronidase also indicated the presence of the two mucopolysaccharides.

In addition to various routine stains, including Laidlaw's reticulin stain, the following methods were used: (1) azure A, $0.01 \%$ in $30 \%$ ethanol, with and without alcohol dehydration of the section (Kramer and Windrum, 1954); (2) alcian blue, $0.01 \%$ in $3 \%$ acetic acid (Steedman, 1950), with neutral red and chlorantinfast red counterstains; (3) toluidine blue, $0.5 \%$; (4) Hale's dialysed iron method for acid mucopolysaccharides (Thompson, 1966); (5) Gomori's aldehyde fuchsin (Scott and Clayton, 1953), and the aldehyde fuchsin-alcian blue sequence described by Spicer and Mayer (1960); (6) periodic-acid-Schiff reaction (PAS).

\section{ENZYMIC DIGESTION}

A number of sections from various areas were stained with azure A, toluidine blue, alcian blue, and Hale's method before and after extraction with bovine testicular hyaluronidase (Pearse, 1960), and staphylococcal hyaluronidase ${ }^{1}$. This latter, like streptococcal hyaluronidase, digests only non-sulphated acid mucopolysaccharides (Meyer, 1947; Linker, Hoffman, Meyer, Sampson, and Korn, 1960). The experimental sections were incubated for $3 \mathrm{hr}$ at $37^{\circ} \mathrm{C}$ in bovine and bacterial hyaluronidase prepared at a concentration of $1 \mathrm{mg} / \mathrm{ml}$ in normal saline. The controls were stained after incubation in normal saline only. Comparing the staining after incubation in saline with untreated stained sections showed a reduction in intensity suggesting that incubation in normal saline removed some of the polysaccharide. This observation needs further investigation.

\section{RESULTS OF CHEMICAL ANALYSES}

The qualitative analysis of the tumour tissue by extraction with sodium acetate showed that both hyaluronic acid and chondroitin sulphate were present. Analysis of the pepsin digest showed that a further portion of hyaluronic acid had been extracted. These results are summarized in Table I. The quantitative results showing the amounts of mucopolysaccharide extracted from the tumour tissue are given in Table II.

${ }^{1}$ Organon Laboratories Ltd. 
TABLE I

CHEMICAL ANALYSIS OF TUMOUR TISSUE

Electrophoresis of

Sodium Acetate Extract against

Known Standards ${ }^{1} \quad$ Pepsin Digest

Hyaluronic acid and chondroitin Hyaluronic acid only present sulphate

${ }^{1}$ Hyaluronic acid, Koch Light Co. Chondroitin sulphate, Koch Light Co.

TABLE II

ANALYSIS OF MUCOPOLYSACCHARIDES FROM

$4 \cdot 3 \mathrm{~g}$ TUMOUR TISSUE USING A SEPHADEX COLUMN

\begin{tabular}{|c|c|c|c|c|}
\hline \multicolumn{4}{|c|}{$\begin{array}{l}\text { Fraction Eluted in } \mathrm{M} \mathrm{NaCl} \\
\text { in } 0.01 \mathrm{M} \mathrm{HCl}\end{array}$} & \multirow{2}{*}{$\begin{array}{l}\text { Weight of } \\
\text { Mucopoly- } \\
\text { saccharide } \\
\text { (mg) }\end{array}$} \\
\hline$I$ & $I I$ & III & $I V$ & \\
\hline 0.50 & $1 \cdot 25$ & $1 \cdot 50$ & 2.00 & \\
\hline
\end{tabular}

Hyaluronic acid NaOAc extract

Pepsin digest

Chondroitin sulphate

NaOAc extract

Pepsin digest

Total

\begin{tabular}{|c|c|c|c|}
\hline+ & - & - & - \\
\hline & - & - & - \\
\hline- & + & + & - \\
\hline & - & - & - \\
\hline
\end{tabular}

HISTOCHEMISTRY

ROUTINE STAINS These showed a general microscopical structure of interlacing narrow bundles of collagen, fine collagen and probably reticulin fibres with large areas of intercellular mucinous material through which ran fine fibres (Figs. 2-4). Pools of mucin and small scattered foci of compact collagen were present. The tissue was only moderately vascular. The greater the quantity of mucin the less dense was the collagen-reticulin component. The morphology of the bipolar and stellate cells of the tumour bore only a superficial resemblance to those of embryonic myxomatous tissue (Fig. 6). Only an occasional mast cell was present in a low-power field. New bone formation was taking place from the exposed periosteum (Fig. 7).

AZURE A AND TOLUIDINE BLUE The mucin was generally highly metachromatic but in some areas varied in intensity.

HALE'S METHOD AND ALCIAN BLUE These stains produced strongly positive results and paralleled the metachromatic reactions, but gave a more striking contrast between the mucin and the fibre structure.

PERIODIC ACID-SCHIFF The mucin did not stain but the collagen fibres appeared pale pink and the finer fibres had the reddish colour of reticulin.
GOMORI'S ALDEHYDE FUCHSIN The staining of the mucin was only moderate with areas of weake coloration. This stain was also used in conjunction? with alcian blue according to the method of Spice? and Meyer (1960) and although the aldehyde fuchsin-alcian blue (AF.AB) sequence suggested demonstration of both sulphated and non-sulphate $\$$

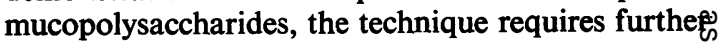
investigation.

\section{ENZYME DIGESTION}

TESTICULAR HYALURONIDASE Metachromasia, alcią blue, and Hale staining of the mucin were abolished after incubation with the enzyme (Figs. 5 and 6) This reaction, together with the metachromatiog reactions and positive results with Hale's method and alcian blue, indicated the presence of acid mucos polysaccharide. Slight metachromasia of the fine fibres was noted, particularly in the thicker section $\$$ treated.

STAPHYLOCOCCAL HYALURONIDASE The resulto showed a reduction in the amount of metachromatic mucin and also in the intensity of staining witk Hale's ferrocyanide solution and alcian blue. This was also confirmed in four other oral myxomasp three of them from the jaw bones. Figures 8 and $\$$ are an attempt to illustrate this reduction in staining intensity. The observation made earlier that soms mucopolysaccharide appeared to be lost in th saline-incubated section does not affect the reduction illustrated here since the sections treated wit? bacterial hyaluronidase are compared with the control saline-treated sections; the reduction was somewhat greater compared with the normalli prepared sections. The reduction in staining after treatment with the bacterial enzyme was apparently due to digestion of the hyaluronic acid component.

\section{DISCUSSION}

The chemical analysis showed that the myxoma contained hyaluronic acid and chondroitin sulphate The quantitative analysis indicated that of the two acid mucopolysaccharides present, hyaluronic acid formed the larger component amounting to $80 \%$ of the total mucopolysaccharide; $44.5 \%$ of the tot mucopolysaccharide was protein-bound hyaluroni这 acid. The chemical analysis confirmed the results suggested by the histochemical tests. The various histochemical methods used indicated the presence of acid mucopolysaccharide which was entirely digested by testicular hyaluronidase. Digestion wite bacterial hyaluronidase, however, did not remove a the metachromatic, alcian blue, and Hale-positive 


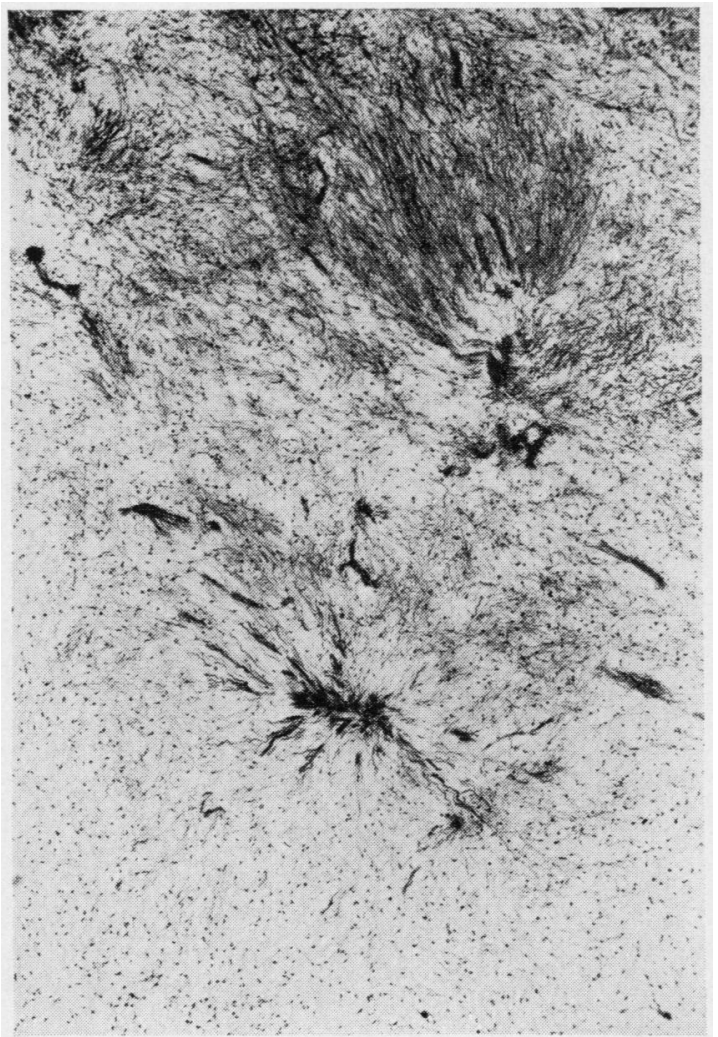

FIG. 2 .

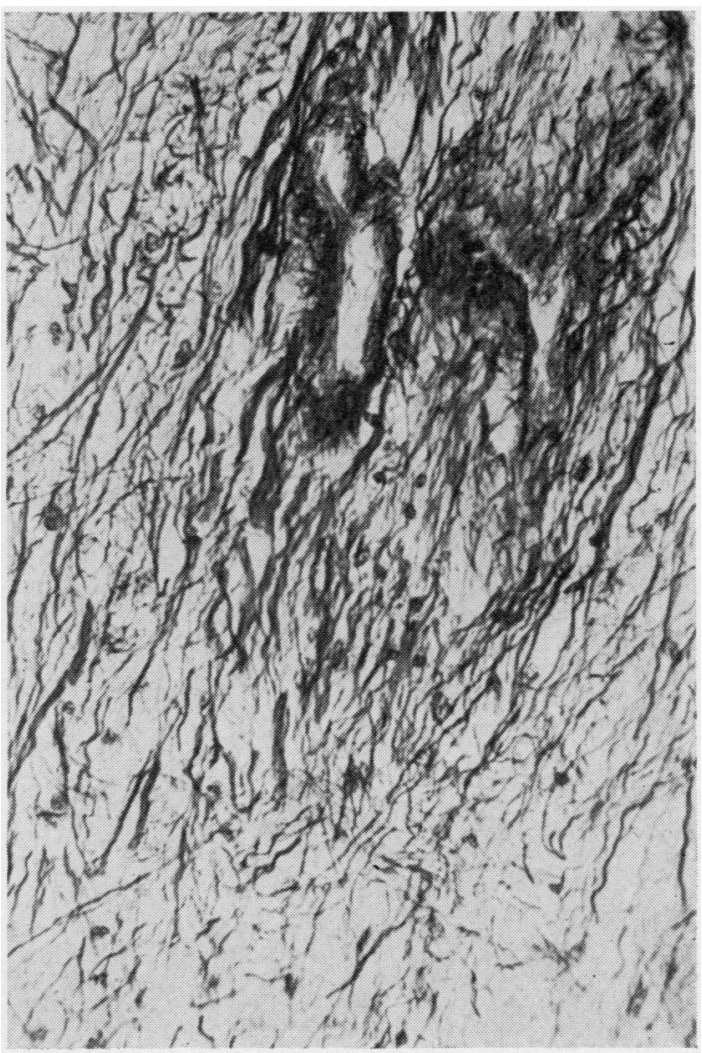

FIG. 3.

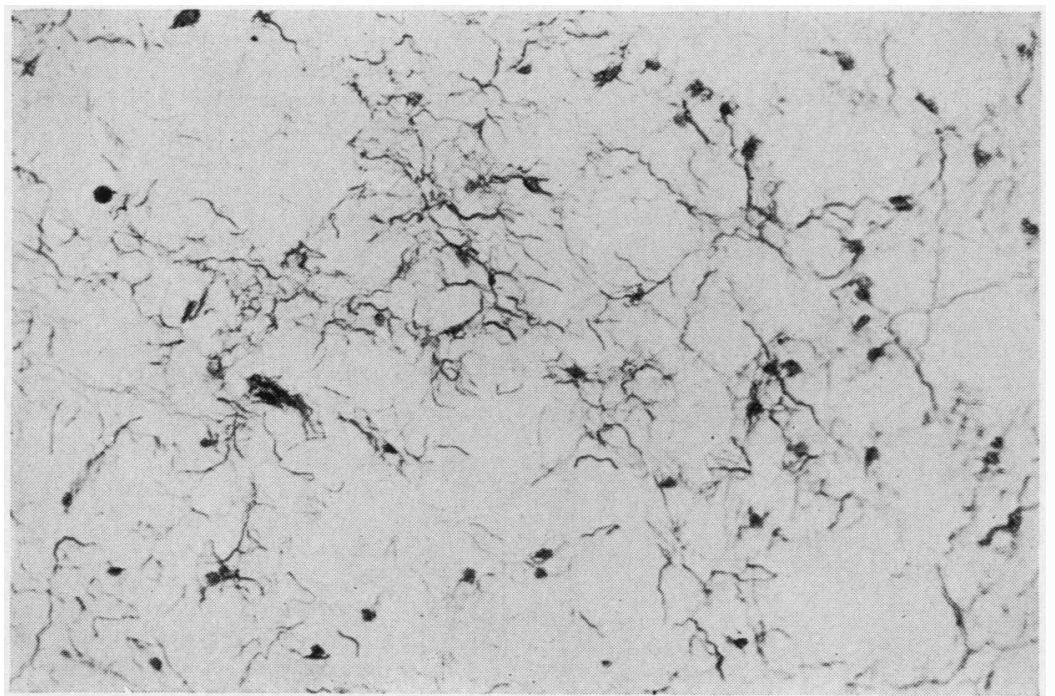

FIG. 4.
FIG. 2. A low-power view of an area of irregularly orientated, mostly narrow, bundles of collagen fibres with intervening myxomatous areas leading into myxomatous tissue of the bulk of the tumour. Haematoxylin and Masson's light green $\times 42$.

FIG. 3. Higher magnification of narrow collagen bundles and irregularly orientated fibres becoming sparser below, the latter comprising the bulk of the

tumour. A vessel is shown in the top half. Laidlaw's reticulin, $\times 225$.

FIG. 4. Sparse collagen and reticulin fibres irregularly orientated within and round mucopolysaccharide-ground substance. Laidlaw's reticulin, $\times 225$. 

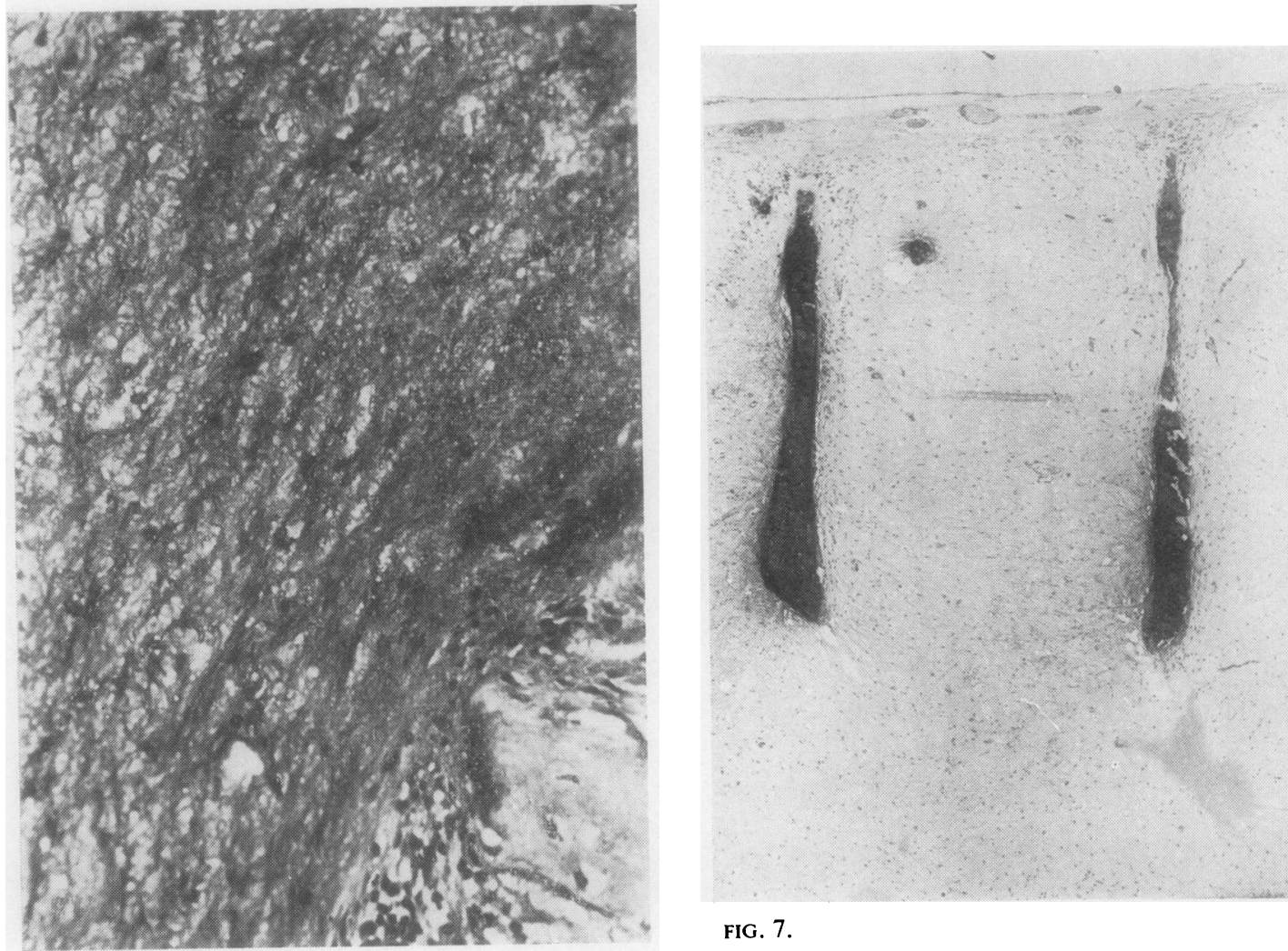

FIG. 7.

FIG. 5.

FIG. 5. Higher power of aret

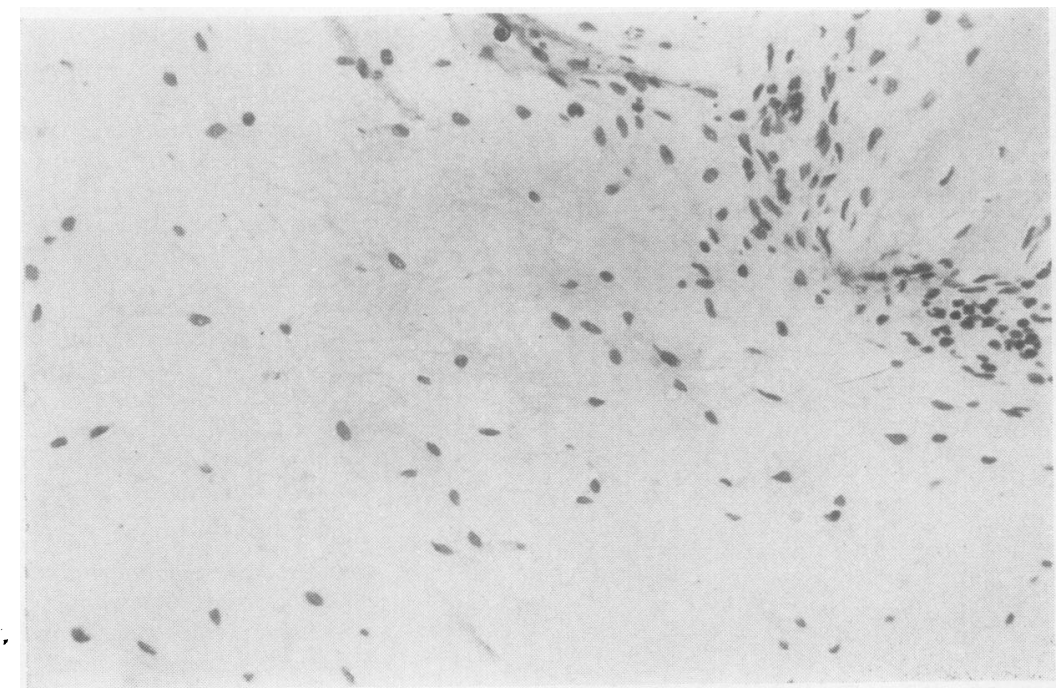
bone (lower right), showi metachromasia of highly mucinous tissue. Control section for Fig. 7 incubated in saline, undecalcified; toluidine blue, $\times 225$.

FIG. 6. Loss of mucin in adjacent section after digestion with testicular hyaluronidase Note widely spaced mucopoly saccharide-producing cells, N and bone as in Figure 5. Undecalcified; toluidine blue, $\times 225$.

FIG. 7. Part of area where myxoma resorbed cortical 0 bone. Bony spicules have $\bar{\Phi}$ developed from the periosteum seen at the lower border; 0 compare Figure 1. Intervenifg tissue pure myxoma. Haematoxylin and eosin, $\times$

FIG. 6 . 


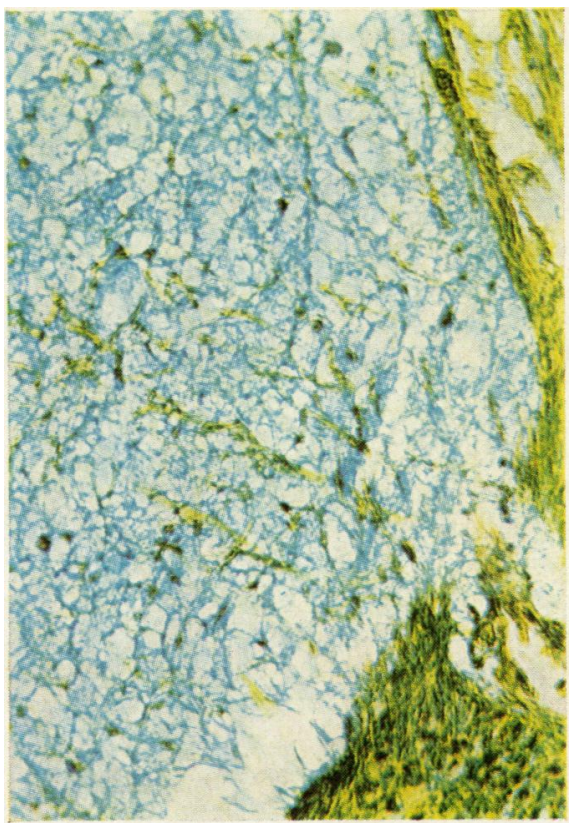

FIG. 8 .

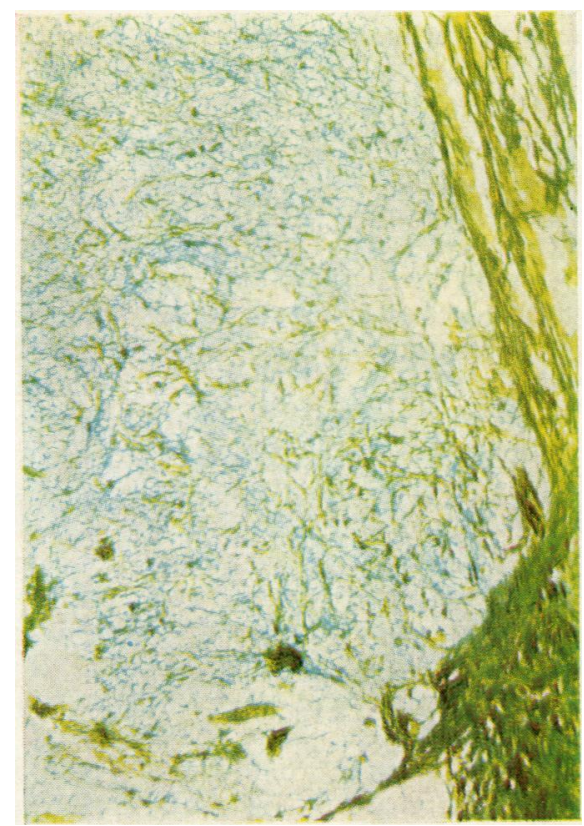

FIG. 9.
FIG. 8. Area near periosteum. Control section for Fig. 9 incubated in saline. Hale's dialysed iron and metanil yellow, $\times 225$.

FIG. 9. Adjacent section after digestion with staphylococcal hyaluronidase showing reduction in staining due to loss of hyaluronic acid. Hale's dialysed iron and metanil yellow, $\times 225$. material. As staphylococcal, like streptococcal, hyaluronidase only digests hyaluronic acid, the reduction in staining suggested that hyaluronic acid had been removed.

The results support Stout's (1948) original idea that the myxoma might contain hyaluronic acid although he cited this as the only component. The findings do not support Grishman (1952), Tighe and Meachim (1962), and Tighe (1963) who consider that the mucopolysaccharide present is chondroitin sulphate. Their investigations, however, were confined to studies of soft tissue myxomas. Tighe and Meachim (1962) and Tighe (1963) used histochemical methods together with testicular hyaluronidase, and in addition the former authors used radioactive sulphate fixation. Grishman (1952) used both testicular and bacterial hyaluronidase but was unsuccessful with the latter.

In the sections examined, no specific foci of mucin entirely digested by the bacterial enzyme could be detected and it would appear that both sulphated and non-sulphated acid mucopolysaccharides were probably mixed together. The different areas stained by aldehyde fuchsin and alcian blue, using the technique of Spicer and Meyer (1960) to differentiate acid mucopolysaccharides, suggest, however, the possibility that some of the stellate cells may be limited to the production of either sulphated or non-sulphated mucopolysaccharides, ie, may not be products of the same cell. Further techniques need to be developed to localize the origin of the different polysaccharides. The similarity of the microscopic structure between the jaw myxomas and those in other sites suggests the possibility that all myxomas probably contain at least two mucopolysaccharides. Meyer et al (1956) from their chemical analytical studies suggest that tumours of mesodermal origin produce only one type of mucopolysaccharide, the sulphated group as in the chondrosarcoma or hyaluronic acid as in the liposarcoma. In our case, however, we found two types present with hyaluronic acid as the larger component. It is interesting that other tumours with mucinous areas have been found to contain hyaluronic acid, as for instance the liposarcoma (Meyer et al, 1956; Tighe, 1963). Our histochemical and enzyme studies of a case of liposarcoma showed the presence of both hyaluronic acid and chondroitin sulphate. In 13 of the 16 mesiotheliomas analysed by Wagner et al (1962), streptococcal hyaluronidase removed all the metachromasia in the sections, indicating the presence of hyaluronic acid only. Chemical analysis of the pleural fluids from five cases showed the presence of hyaluronic acid.

Although the metachromasia of hyaluronic acid is said to be weaker than the sulphated mucopolysaccharides, Tighe (1963) thought that its concentration in tissues was probably never high 
enough to contribute to metachromasia; however, umbilical cord shows a positive metachromasia presumably largely due to hyaluronic acid. Meyer (1947) found a concentration of about $1 \%$ showed typical metachromasia in smears. In the present study it would appear that the quantity of hyaluronic acid present was sufficient to affect the intensity of the metachromasia after bacterial digestion; this was also supported by the observable reduction in the intensity of the staining using Hale's colloidal iron method and alcian blue.

The controversial question of fixation of tissue for demonstrating acid mucopolysaccharides is worthy of comment here. Tighe (1963), quoting Grishman (1948), states that as hyaluronic acid is soluble in water, formol saline fixation is not recommended. Pearce et al (1952) considered that mucin stains on formalin-fixed tissue yielded inconclusive results. In our histochemical controls, umbilical cord fixed in both buffered formol-saline and Carnoy's fixative showed little difference in the staining of the mucin. Using the bacterial enzyme we found a striking loss of mucopolysaccharide, apparently hyaluronic acid and an undigested amount mostly round the central vessels of chondroitin sulphate. In a full discussion on the question of fixation and mucopolysaccharides, Curran (1961) found that formalin is an excellent fixative but draws attention to the 'unpredictability of fixation in general and fixation of acid mucopolysaccharide in particular'.

There is strong evidence that the 'fibroblast cell' is responsible for the production of both hyaluronic acid and the sulphated acid mucopolysaccharides (Gersh and Catchpole, 1949; Curran and Kennedy, 1955; Grossfeld, Meyer, and Godman, 1955; Meyer et al, 1956; Green and Hamerman, 1964; Curran, Lovell, and Clark, 1966). Asboe-Hansen (1950) suggests that mast cells are the main source of hyaluronic acid. The few mast cells present in the jaw myxoma does not suggest that they are the source of the hyaluronic acid. Kennedy (1960) states that on topographical grounds the fibroblast is probably responsible. As previously suggested it would appear that in the present tumour the stellate cells produced both sulphated and non-sulphated mucopolysaccharides, although it is possible that each substance may be the product of a different stellate cell.

Tighe and Meachim (1962), following up Meyer's (1951) suggestion that fibroblasts secrete acid mucopolysaccharides together with a soluble protein, 'pre-collagen', consider that sulphated mucopolysaccharides are involved in collagen formation and put forward the idea that the stellate cells of myxomatous tissue produce sulphated mucopolysaccharides but fail to form precollagen, thus accounting for the accumulation of mucin and a paucity of fibres, or in other words, "the retention of muciss within the growth and the relative failure of fibre production'. As the quantity of hyaluronic acid our case is not normal for connective tissue itself cannot be considered a 'retention' substance. On t basis of our results, the high hyaluronic acid and the minor sulphated mucopolysaccharide content couved explain the paucity of collagen fibres characteris of the tumour. However, chemical analyses of tissie cultures of one line of mouse fibroblasts have suggested that during collagen synthesis the pot saccharide produced by the same cells probabły consists almost exclusively of hyaluronate. It is of particular interest that another fibroblast lifie appeared to lose its ability to synthesize collagen but continued to synthesize hyaluronate at the sange rate as the previous line (Green and Hamermant, 1964). It is suggested that the more mucinous the tumour the more likely it is to be aggressive. Currog et al (1956) have further elucidated the role off mucopolysaccharides in fibrogenesis by light- a $\bar{d}$ electron-microscope techniques. The question arises whether the secretion of a larger quantity than normal of hyaluronic acid is a sign of severe metabogec disturbance of the stellate cell and whether perhaps this plays a role in its neoplastic behaviour. The postulation of merely a reversion to embryol connective tissue is not consistent with the invasipe and destructive behaviour of the myxoma. Meyer et al (1956) noted with surprise the differences on mucopolysaccharides in view of the relative hist logical similarity of the tissues and especially of the cells which are believed to produce the acid poFsaccharides'.

Since little fibre production is taking place in the purer forms of myxoma we believe that the stellate cell is in fact a mesenchymal cell which has failed $\mathbf{B}_{0}$. differentiate sufficiently to play its role in collagen formation, ie, it is not strictly a collagen-producim, mucopolysaccharide-secreting fibroblast, but oa mesenchymal cell (or metabolically poorly differentiated or immature fibroblast) secreting mucopotysaccharides in excessive and abnormal proportions.

This ability to produce mucin appears to besa property of an active viable cell and it is almast certainly wrong to postulate a degenerative process, as most writers do when describing the myxoma gr fibromyxoma as a fibroma undergoing myxomatous degeneration. The old term 'myxoblast' would bea suitable name for the mucopolysaccharide-secreting mesenchymal cell and would serve to distinguish it from the collagen-mucopolysaccharide-producieg fibroblast. The myxoma would then be considere 巾 $^{+}$

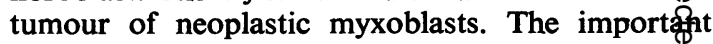
histogenetic point here is that 'myxomatous qe- 
generation' of a fibroma postulates a prior formation of fibrous tissue, whereas we suggest an initial formation of mucopolysaccharide by a cell producing little or no precollagen and hence little or no fibre formation and which has become neoplastic. Non-neoplastic mucopolysaccharide-producing cells are common enough in the granulation tissue of inflammatory lesions, the stroma of neoplastic tissue and indeed in the fibroma itself.

The collagen found in varying amounts in all myxomas indicates that thereare present mesenchymal cells which have differentiated into collagenproducing fibroblasts. Stout (1948) suggests that the collagen present is akin to the fibrosis seen in many tumours but the morphology is not suggestive of this. The term 'fibromyxoma' is used where there is an appreciable fibrous content. It would be interesting to know whether in the largely fibrous tumours (fibromas) the intercellular ground-substance is chondroitin sulphate and whether the highly mucinous myxoma tumours are characterized by a high hyaluronic acid component as in the present case.

We are indebted to Professor W. Bartley for his help and advice with the chemical analysis, to Mr M. Rudland, FIMLT for technical assistance, to Mr S. Ireland, FDS, RCS, for the specimen, and to Organon Laboratories Ltd for the gift of the staphylococcal hyaluronidase.

\section{REFERENCES}

Asboe-Hansen, G. (1950). Ann. rheum. Dis., 9, 149.
Balazs, E. A., and Jeanloz, R. W. (1965). The Amino Sugars, p. 219. Academic Press, New York.

Bauer, W. H., and Harell, A. (1954). J. Bone Jt Surg., 36-A, 263.

Bitter, T., and Muir, H. M. (1962). Anal. Biochem., 4, 330.

Curran, R. C. (1961). Biochemical Society Symposia, 20, 24. , and Kennedy, J. S. (1955). J. Path. Bact., 70, 449.

, Lovell, D., and Clark, A. E. (1966). Ibid., 91, 429.

Dische, Z. (1947). J. Biol. Chem., 167, 189.

Gersh, I., and Catchpole, H. R. (1949). Amer. J. Anat., 85, 457.

Green, H., and Hamerman, D. (1964). Nature (Lond.), 201, 710.

Grishman, E. (1948). Bull int. Ass. med. Mus., 28, 104.

- (1952). Cancer (Philad.), 5, 700.

Grossfeld, H., Meyer, K., and Godman, G. (1955). Proc. Soc. exp. Biol. (N.Y.), 88, 31 .

Heremans, J., and Vaerman, J. P. (1958). Clin. chim. Acta, 3, 430.

Kennedy, J. S. (1960). J. Path. Bact., 80, 359.

Kramer, H., and Windrum, G. M. (1955). J. Histochem., 3, 227.

Linker, A., Hoffman, P., Meyer, K., Sampson, P., and Korn, E. D. (1960). J. biol. Chem., 235, 3061.

Meyer, K. (1947). Phj'siol. Rev., 27, 335.

- (1951). Connect. Tissues, Trans. Confs. Josiah Macy Jr Fdn, 1, 32.

-, Davidson, E., Linker, A., and Hoffman, P. (1956). Biochim. biophys. Acta (Amst.), 21, 506.

Näntö, V. (1963). Acta chem. scand., 17, 857.

Pearce, A. E., Weller, R. W., and Steinberg, N. (1952). Arch. Surg., 64, 835 .

Pearse, A. G. E. (1960). Histochemistry, 2nd ed. Churchill, London.

Perou, M. L., Kolis, J. A., Zaeske, E. V., and Borja, S. R. (1967). Cancer (Philad.), 20, 1030.

Sedano, H. O., and Gorlin, R. J. (1965). Arch. oral Biol., 10, 727.

Schmidt, M. (1962). Biochim. biophys. Acta (Amst.), 63, 346.

Scott, H. R., and Clayton, B. P. (1953). J. Histochem., 1, 336.

Spicer, S. S., and Meyer, D. B. (1960). Amer. J. clin. Path., 33, 453.

Steedman, H. F. (1950). Quart. J. micr. Sci., 91, 477.

Stout, A. P. (1948). Ann. Surg., 127, 706.

Thompson, S. W. (1966). Selected Histochemical and Histopathological Methods. Thomas, Springfield, III.

Tighe, J. R. (1963). J. Path. Bact., 86, 141.

and Meachim, G. (1962). Ibid., 83, 195.

Wagner, J. C., Munday, D. E., and Harington, J. S. (1962). Ibid., 84, 73. 